\title{
Impact of the Internet on the Ability of Retail Enterprises to Operate Lu Qinghua
}

Tianjin Coastal Polytechnic,300450

\section{Keywords: Internet, retail enterprise, impact ability}

\begin{abstract}
With the further development of the market economic system, the management activities of all social sectors have achieved innovative development. As a special kind of industry, retail enterprises are mainly an intermediary, mainly from the manufacturing companies or wholesale enterprises to buy goods and services, and then resell the goods to the consumer industry. It can be said that retail enterprises have made positive contributions to stimulating consumption and relieving employment pressure. At the same time, in the era of the Internet, retail enterprises have realized the transformation and innovation in business. This paper analyzes the impact of the Internet on the operating capabilities of retail enterprises under the new situation, and proposes effective countermeasures to enhance the competitiveness of retail enterprises in the Internet era. This research content has far-reaching impact on the development of traditional retail and market economy.
\end{abstract}

\section{Introduction}

In the Internet era, the e-commerce industry has developed rapidly and has also driven new social trends. More and more consumers choose the way of online consumer shopping, it can be said that the Internet era brings new trends and trends to the development of traditional retail enterprises. Under this circumstance, how to grasp opportunities and develop more competitive advantages for retail enterprises has become an important topic for many retail enterprises to explore and innovate.

\section{Impact of the Internet on the Ability of Retail Enterprises to Operate}

As an important technical means for the management of corporate economic activities, the Internet can form an orderly management of the economic expenditures and benefits of enterprises, improve the operating efficiency of enterprises, and form a good guarantee for business management. The main role of Internet technology in business management can be reflected in the following points.

(1) The Internet is the basic premise of the operation and management activities of modern retail enterprises. In the era of Internet + , retail in the business management activities needs to be based on the development of enterprises, with the help of the new model of online transactions, the retail enterprise's business innovation. This requires a certain guarantee of business technology, requiring retail enterprises to combine the online and online marketing management methods according to the characteristics of their own products and services, so as to grasp the best way of operating sales.

(2) The Internet is an important guarantee for the operating efficiency of retail enterprises in the new era. In the development of business operations, the company obtains economic income by sales of products or services, and enterprises want to achieve healthy development, they need to maintain good economic income, sell more products and services, and thus form business benefits. This requires grasping the social trends and the development of the industry in the era of the Internet, and using the new technologies of the network to realize the product development and product promotion of the enterprise. Therefore, it is necessary to introduce Internet technology and information system to form an effective management of the operation and operation of retail enterprises, and obtain the maximum benefit output with the least capital investment, thus forming a good guarantee for the improvement of business operation efficiency.

(3) The Internet provides a good guarantee for business operations. The development of retail enterprise operation is inseparable from the operation of marketing means. The development of 
current network marketing technology has driven retail business operations to reach a new situation. At the same time, retail companies are required to take advantage of the development advantages of the Internet + , continuously expand the production of enterprises, and continuously improve the operating income of enterprises, and provide impetus for the in-depth operation and development of enterprises. In the current fierce market competition, corporate operations are not only subject to external competitive pressures, but also under pressure from internal operations management. Therefore, it is necessary to improve the effectiveness of retail enterprises through Internet support.

\section{Countermeasures for Retail Enterprises to Improve Their Operating Ability Under the Internet}

The application of Internet technology in business management can strengthen the optimization and innovation of the internal and external management systems of retail enterprises, form a unified management of the strategic business objectives of retail enterprises, reduce the way for retail enterprises to take the road, and bring unnecessary cost expenditures, thus expanding retail business operating efficiency. With the support of Internet technology, the optimization of the operating capabilities of retail enterprises can be improved from the following aspects.

(1) Improve the understanding of the Internet concept. The management and management of modern enterprises needs to be updated in terms of management concepts and management methods. The improvement of retail enterprises' operational capabilities must be based on the development concept of the Internet and the technical means of the Internet. In the new era, we need to actively seek organic integration with the Internet. At the leadership and management of retail enterprises, we are required to be able to develop a comprehensive understanding of the Internet development trend, thus forming a network management technology. Fully popularize and strengthen education and management training to enhance the awareness and attention of enterprise personnel on the operation and management of Internet + retail enterprises.

(2) The new network department is set up and staffed. For retail enterprises, the realization of networked development has become the key to improving the ability of retail enterprises to operate. However, in order to truly develop the business development of retail enterprises by means of network technology and network theory, it must be able to optimize the internal management activities of retail enterprises. It builds a specialized network department and is equipped with specialized network technology talents to enable the sustainable development of online marketing and network promotion of retail enterprises.

(3) Improve the level of information construction of the Internet. In the context of the information age, the management and development of retail enterprises are inseparable from information technology, and the management efficiency and quality of massive information resources affect the internal management of enterprises and the development of external operations. Therefore, we need to comprehensively improve the needs of the entire enterprise to improve the level of informatization construction, and introduce information management tools to continuously improve the modern development advantages of business management. For one thing, enterprises need to introduce information systems and information platforms in the financial management system. For example, the EPR system improves the scientific management of financial management and the efficiency of financial data analysis, and provides a more accurate and meticulous information foundation for the management of retail enterprises. For another, the Internet should establish relevant systems and platforms, implement comprehensive planning of internal databases in the financial management system, and provide an effective information foundation guarantee for economic activities of enterprises through the integrated mode of operating production services.

(4) Diversification of financing channels for retail enterprises. In the new era, the important challenge of the business development of retail enterprises is that the scale of retail enterprises is small, it is difficult to form an industrial scale, and they have the advantage of industrial development. Therefore, in the process of informatization construction and management, it is inevitable that the internal organization structure of retail enterprises is incomplete, which will hinder the transformation and upgrading of retail enterprises. Therefore, it is imperative to be able 
to do a good job in the investment and financing management activities of retail enterprises, and to create a diversified financing channel for retail enterprises by means of network technology, thereby escorting the management activities of retail enterprises. Therefore, according to the financing status of retail enterprises and the actual situation of retail enterprises, choose appropriate financing channels to promote the scientific development of enterprises. In the diversified development of corporate financing channels, the transformation and development of enterprises is also easier to implement, which can promote the establishment of cooperative relations between enterprises and banks, form the investment and financing effect of sharing interests and risks, and reduce the operational risks of enterprises.

(5) Do a good job in building an internal optimization system for retail enterprises. A good corporate culture is conducive to enhancing the cohesiveness and core competitiveness of the company. At present, with the support of network information technology, retail enterprises are required to use the network platform to display corporate culture and do a good job in talent cultivation. More importantly, it is necessary to use the modern information technology to carry out optimization and innovation of the management system of retail enterprises. For example, the oa system is introduced in the enterprise to realize the sharing of information in the marketing management and after-sales of the retail enterprise. At the same time, the use of big data technology means to carry out marketing and promotion of the company's products, launch the accurate delivery of advertising, and better launch their own brand strategy. More importantly, it is required that retail enterprises can adopt the modern enterprise management concept, carry out the organizational structure of the enterprise, set the strategic goals of the enterprise, and do a good job in the modern human resource management, financial cost budget and other content of the enterprise. At the same time, it can also improve the professionalism and innovation of personnel, and continue to bring innovation to all aspects of retail business.

\section{Conclusion}

In summary, the Internet era has brought new changes to the management model of retail enterprises, which has changed the business objectives and decision-making of retail enterprises. Under this circumstance, if retail enterprises want to expand the scale of development, they must be able to grasp the advantages and opportunities under the Internet, and start from the internal control ability of the enterprise to expand the scale of the business. At the same time, companies need to be able to do a good job in the financial management of enterprises and increase their ability to resist risks. Only in this way can we achieve sustainable development through the spring breeze of the Internet era.

\section{References}

[1] Huang Manyu, Li Yuanying. Research on the Influence Path and Effect of the Whole-channel Development Level of Retail Enterprises on Operational Efficiency[J]. Journal of Beijing Technology and Business University (Social Science Edition), 2017, 3206: 35-44.

[2] Rong Chaohe, Han Shuyi. The Impact of the Internet on the Operating Capabilities of Retail Enterprises [J]. Business Economics and Management, 2018, 10: 19-28.

[3] Sun Zhaohui. The Influence of Omni-channel Development on the Operational Efficiency of Retail Enterprises [J]. Business Economics Research, 2019, 01: 104-107.

[4] Wang Shizhen. "Internet +" or "return to the entity"? - Consumption model and strategic choice of retail enterprises [J]. Business Economics and Management, 2019, 03: 20-28. 